\title{
ANALISIS KUALITAS PELAYANAN PADA BAGIAN KLAIM BERDASARKAN TINGKAT KEPUASAN NASABAH DI PT. AJC MENGGUNAKAN METODE SERVICE QUALITY
}

\author{
Muhammad Kholil dan Siti Hanifah \\ Program Studi Teknik Industri Universitas Mercu Buana \\ e-mail: m.kholil2009@gmail.com
}

\begin{abstract}
ABSTRAK
PT. AJC adalah sebuah perusahaan asuransi jiwa yang telah melalui tiga dekade dan terus berkembang. Strategi untuk memenangkan persaingan dapat dilakukan dengan cara meningkatkan kualitas layanan, salah satu indikator yang paling banyak dipakai untuk mengukur kualitas layanan adalah tingkat kepuasan pelanggan. Penelitian ini bertujuan untuk mengetahui tingkat kepuasan pelanggan terhadap kualitas layanan bagian klaim PT. AJC Jakarta, menggunakan metode survey dengan instrumen kuesioner. Tingkat kepuasan pelanggan diukur menggunakan model SERVQUAL (Service Quality) terhadap 5 dimensi kualitas layanan yaitu tangible, reliability, responsiveness, assurance dan emphaty. Berdasarkan analisis service score, dapat diketahui bahwa kualitas pelayanan mendapatkan hasil gap yang positif (+) yang berarti kualitas pelayanan sesuai dengan harapan nasabahnya. Dimensi yang memiliki tingkat kepuasan tertinggi adalah dimensi tangible; atribut yang memiliki tingkat kepuasan tertinggi adalah perlengkapan sarana dan ruang pelayanan, dan atribut yang terpetakan pada grafik Kartesius terbanyak adalah pada kuadran II yang berarti kualitas layanan bagian klaim yang diteliti menunjukkan cukup baik. Hasil perhitungan menunjukkan bahwa bagian klaim PT. AJC telah mampu memberikan kualitas pelayanan yang sesuai dengan harapan nasabahnya.
\end{abstract}

Kata kunci: Asuransi, Dimensi Kualitas, Kepuasan Nasabah, Kualitas Pelayanan.

\begin{abstract}
PT. AJC is a life insurance company as one of the insurance company through three decades and continues to grow. Strategies for winning the competition can be done by improving the quality of service, one of the most widely used indicator to measure the quality of service is the level of customer satisfaction. The objective of this research is to identify satisfaction level of service quality of PT. AJC Insurance Jakarta, using the method of survey. This research using survey method with quisionaire Single Cross Sectional Study approaches. Research using Servqual (Service Quality) model use five dimensions of service quality, that was tangible, reliability, responsiveness, assurance, and emphaty. Based on the analysis of service score, can be known that the quality of service get a positive gap (+) that means the quality of service inconformity with expectation its customers. Dimensions has the highest complain is tangible dimension; attribute has the highest complence is room service facilities and equipment, and attributes are mapped on a cartesius graphis on second-quadrant, that means the quality of service department claim showing good enough. A result of calculation shows that the department clam of PT. AJC has been able to give service quality in conformity with expectation its customer.
\end{abstract}

Keywords: Insurance, Quality Dimensions, Service Quality, Customer Satisfaction.

\section{PENDAHULUAN}

PT. AJC sebagai badan usaha yang bergerak di sektor jasa khususnya asuransi, dituntut untuk dapat menciptakan bisnis dengan memberikan pelayanan semaksimal mungkin dalam upaya tetap unggul untuk persaingan jangka panjang dengan menawarkan janji berupa jaminan kepastian dalam pelayanan asuransi bagi nasabahnya, terutama pelayanan bagian klaim. Hal ini disebabkan karena kualitas jasa dapat digunakan sebagai alat untuk mencapai keunggulan kompetitif.
Metode Servqual (Service and Quality) digunakan untuk mengetahui ktriteria-kriteria kualitas yang harus ditingkatkan kualitas pelayanannya berdasarkan gap yang terjadi antara persepsi dan harapan pelanggan. Di antara berbagai model pengukuran kualitas pelayanan (Servqual), Servqual merupakan metode yang paling banyak digunakan karena frekuensi penggunaannya yang tinggi, servqual dipandang memenuhi syarat validitas secara statistik. 
Adapun tujuan yang ingin dicapai dalam penelitian ini penelitian ini adalah: untuk menganalisis pengaruh bukti fisik (tangible), keandalan (realibility), daya tanggap (responsiveness), jaminan (assurance), dan peduli (empaty) terhadap kualitas pelayanan berdasarkan kepuasan nasabah, menganalisis kesesuaian antara persepsi dan harapan konsumen terhadap kualitas layanan pada bagian klaim, mengetahui dimensi Service Quality yang paling dominan berpengaruh terhadap kualitas pelayanan nasabah PT. AJC.

\section{Kualitas Pelayanan}

Kualitas pelayanan adalah tingkat keunggulan yang diharapkan dan pengendalian atas tingkat keunggulan tersebut untuk memenuhi keinginan pelanggan. Apabila jasa atau pelayanan yang diterima atau dirasakan (perceived service) sesuai dengan yang diharapkan, maka kualitas jasa atau pelayanan dipersepsikan baik dan memuaskan. Jika jasa atau pelayanan yang diterima melampaui harapan pelanggan, maka kualitas jasa atau pelayanan dipersepsikan sebagai kualitas yang ideal. Sebaliknya jika jasa atau pelayanan yang diterima lebih rendah daripada yang diharapkan, maka kualitas jasa atau pelayanan dipersepsikan buruk [1].

\section{Kepuasan Pelanggan}

Kepuasan pelanggan adalah persepsi pelanggan bahwa harapannya telah terpenuhi atau terlampaui [2]. Bila sebuah produk atau jasa memenuhi atau melampaui harapan pelanggan, maka pelanggan merasa puas. Menurut Kotler, kepuasan adalah perasaan senang atau kecewa seseorang yang muncul setelah membandingkan antara persepsi terhadap kinerja (hasil) suatu produk dan harapan-harapannya. Jika kinerja berada di bawah harapan, maka pelanggan tidak puas [3]. Jika kinerja memenuhi harapan, maka pelanggan puas. Jika kinerja melebihi harapan, pelanggan amat puas atau senang.

\section{Konsep Kepuasan Pelanggan}

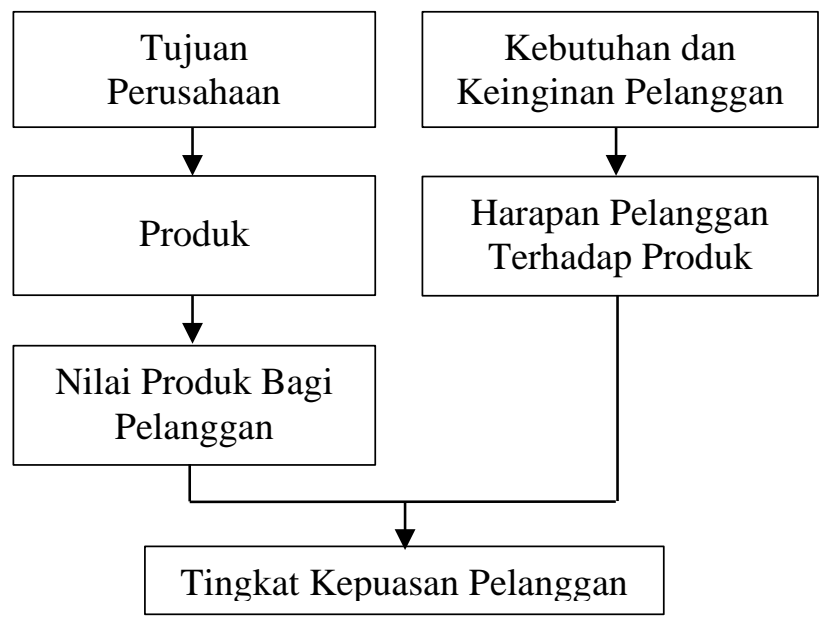

Gambar 1. Konsep Kepuasan Pelanggan [4].

\section{Jasa}

Jasa adalah setiap tindakan atau kegiatan yang dapat ditawarkan oleh suatu pihak kepada pihak lain, yang pada dasarnya bersifat intangible (tidak berwujud fisik) dan tidak mengakibatkan kepemilikan sesuatu [5]. Produksinya dapat dikaitkan dengan produk fisik maupun tidak. Sedangkan Zeithaml mendefinisikan jasa sebagai suatu kegiatan ekonomi yang outputnya bukan produk, jasa dikonsumsi bersamaan dengan waktu produksi dan memberikan nilai tambah, serta bersifat tidak berwujud [6].

Meskipun tidak ada defenisi mengenai kualitas yang diterima secara universal, dari definisi-definisi yang ada terdapat beberapa kesamaan, yaitu dalam elemen-elemen sebagai berikut:

1. Kualitas meliputi usaha mamenuhi atau melebihi harapan pelanggan.

2. Kualitas mencakup produk, jasa, manusia, proses dan lingkungan.

3. Kualitas merupakan kondisi yang selalu berubah (misalnya apa yang dianggap merupakan kualitas saat ini mungkin dianggap kurang berkualitas pada mendatang).

\section{Asuransi}

Asuransi adalah suatu alat untuk mengurangi risiko yang melekat pada perekonomian, dengan cara manggabungkan sejumlah unit-unit yang terkena risiko yang 
sama atau hampir sama, dalam jumlah yang cukup besar, agar probabilitas kerugiannya dapat diramalkan dan bila kerugian yang diramalkan terjadi akan dibagi secara proposional oleh semua pihak dalam gabungan itu [7].

segi hukum adalah: Asuransi atau pertanggungan adalah perjanjian antara 2 (dua) pihak atau lebih dimana pihak tertanggung mengikat diri kepada penanggung, dengan menerima premi-premi Asuransi untuk memberi penggantian kepada tertanggung karena kerugian, kerusakan atau kehilangan keuntungan yang di harapkan atau tanggung jawab hukum kepada pihak ketiga yang mungkin akan diderita tertanggung karena suatu peristiwa yang tidak pasti, atau untuk memberi pembayaran atas meninggal atau hidupnya seseorang yang di pertanggungkan [7].

\section{METODE PENELITIAN}

Teknik pengumpulan data penelitian, antara lain:

1. Kuesioner atau angket

Teknik pengumpulan data dengan kuesioner atau angket disebarkan kepada nasabah dengan tujuan untuk mengetahui tingkat kepuasan nasabah pada bagian klaim di PT. AJC.

2. Observasi

Teknik pengumpulan data ini dilakukan dengan melihat secara langsung bagaimana pelayanan bagian klaim terhadap nasabah. Metode ini merupakan metode pendukung yang akan memperkuat teknik pengumpulan data dengan kuesioner atau angket.

3. Penyebaran Kuesioner

Kuesioner dibagikan sebanyak 35 lembar kepada responden dan diisi sendiri oleh responden. Pertanyaan yang diajukan sebanyak 15 atribut.

\section{HASIL DAN PEMBAHASAN}

\section{Identitas Responden Berdasarkan Jenis Kelamin}

Jenis kelamin (gender) adalah salah satu hal yang terpenting dalam penelitian ini, sebab jenis kelamin responden berpengaruh terhadap jasa pelayanan asuransi perusahaan PT. AJC.
Adapun identitas responden berdasarkan jenis kelamin dapat dilihat pada Tabel 1.

Tabel 1. Identitas Responden Berdasarkan Jenis Kelamin

\begin{tabular}{lcc}
\hline \multirow{2}{*}{ Jenis Kelamin } & Frekuensi & Persentase \\
\cline { 2 - 3 } & (Orang) & $\mathbf{( \% )}$ \\
\hline Laki-laki & 23 & 65,71 \\
Wanita & 12 & 34,29 \\
\hline Jumlah & 35 & 100 \\
\hline
\end{tabular}

Dapat dilihat, berdasarkan tabel tersebut di atas bahwa nasabah yang menjadi responden perusahaan asuransi PT. AJC mayoritas berjenis kelamin laki-laki.

\section{Identitas Responden Berdasarkan Usia}

Usia responden dalam data penelitian ini meliputi usia kurang dari 25 tahun, 26 sampai 35 tahun, 36 sampai 45 tahun dan lebih dari 45 tahun.

Tabel 2. Identitas Responden Berdasarkan Usia

\begin{tabular}{cccc}
\hline \multirow{2}{*}{ No. } & Usia Responden & \multicolumn{2}{c}{ Jawaban Responden } \\
\cline { 3 - 4 } & & Frekuensi & $\begin{array}{c}\text { Persentase } \\
(\%)\end{array}$ \\
\hline 1 & $<25$ tahun & 2 & 5,7 \\
2 & $26-35$ tahun & 13 & 37,1 \\
3 & $36-45$ tahun & 11 & 31,4 \\
4 & $>45$ tahun & 9 & 25,7 \\
\hline & Total & 35 & 100 \\
\hline
\end{tabular}

Proporsi responden menurut Tabel 2. menunjukkan bahwa sebagian besar responden yang menjadi sampel dalam penelitian ini adalah responden yang berumur antara 26-35 tahun yaitu sebesar 13 orang atau sebesar $37,1 \%$. Sedangkan sebagian kecil responden yang berumur kurang dari 25 tahun sebanyak 2 orang atau sebesar 5,7\%. Hal ini menunjukkan bahwa sebagian besar nasabah yang menjadi responden PT. AJC adalah berumur antara 26-35 tahun dan sebagian kecil berumur kurang dari 25 tahun.

\section{Identitas Responden Berdasarkan Tingkat Pendidikan}

Identitas responden mengenai tingkat pendidikan dalam penelitian ini, yaitu mengenai tingkat pendidikan terakhir yang dikelompokkan atas 3, yaitu: SMA, D3 dan 
Sarjana. Untuk lebih jelasnya berikut ini akan disajikan deskripsi karakteristik responden menurut jenjang pendidikan yang dapat dilihat melalui Tabel 3.

Berdasarkan Tabel 3 tingkat pendidikan Sarjana mendominasi dengan persentase sebanyak 71,4\%. Hal ini menunjukkan bahwa sebagian besar tingkat pendidikan nasabah yang menjadi responden PT. AJC adalah berpendidikan Sarjana.
Tabel 3. Identitas Responden Berdasarkan Tingkat Pendidikan

\begin{tabular}{clcc}
\hline & \multirow{2}{*}{$\begin{array}{c}\text { Tingkat } \\
\text { No. }\end{array}$} & \multicolumn{2}{c}{ Jawaban Responden } \\
\cline { 3 - 4 } & Pendidikan & Frekuensi & $\begin{array}{c}\text { Persentase } \\
(\%)\end{array}$ \\
\hline 1 & SMA & 2 & 5,7 \\
2 & D3 & 8 & 22,9 \\
3 & Sarjana & 25 & 71,4 \\
\hline & Total & 35 & 100 \\
\hline
\end{tabular}

Tabel 4. Pertanyaan Kuesioner

\begin{tabular}{ll}
\hline No & Atribut Pertanyaan \\
\hline \multicolumn{2}{l}{ Tangible (Bukti Fisik/X1) } \\
\hline X1.1 $\quad$ Kebersihan dan kenyamanan ruang kantor \\
X1.2 $\quad$ Perlengkapan sarana dan ruang pelayanan \\
X1.3 $\quad$ Peralatan dan teknologi yang dimiliki \\
\hline Reliability (Keandalan/X2) \\
\hline X2.1 $\quad$ Transaksi dilakukan dengan tepat dan bebas kesalahan \\
X2.2 $\quad$ Karyawan mampu memberikan informasi yang diperlukan oleh nasabah \\
X2.3 $\quad$ Prosedur pelayanan klaim yang mudah dimengerti \\
\hline Responsiveness (Tanggapan/X3) \\
\hline X3.1 $\quad$ Respon cepat yang diberikan karyawan kepada nasabah bila ada masalah \\
X3.2 $\quad$ Kecepatan pembayaran klaim \\
X3.3 $\quad$ Kemudahan dihubungi melalui telepon \\
\hline Assurance (Jaminan/X4) \\
\hline X4.1 $\quad$ Ketelitian karyawan saat melayani pelanggan \\
X4.2 $\quad$ Profesionalisme karyawan dalam bekerja \\
X4.3 $\quad$ Tingkat premi yang bersaing \\
\hline Emphaty (Empati/X5) \\
\hline X5.1 & Keramahan dan kesopanan karyawan dalam melayani pelanggan \\
X5.2 & Hubungan interaktif antara karyawan dengan nasabah \\
X5.3 & Etika berkomunikasi melalui telepon \\
\hline
\end{tabular}

Tabel 5. Persentase Distribusi Kepuasan Pelanggan

\begin{tabular}{lcc}
\hline \multicolumn{1}{c}{ Respon } & Distribusi & Persentase (\%) \\
\hline Sangat Tidak Puas & 15 & 2,86 \\
Tidak Puas & 45 & 8,57 \\
Cukup Puas & 220 & 41,90 \\
Puas & 131 & 24,95 \\
Sangat Puas & 114 & 21,71 \\
\hline TOTAL & 525 & 100 \\
\hline
\end{tabular}

Dari Tabel 5 terlihat persentase terbesar, yaitu sebesar 41,90\% menyatakan bahwa nasabah PT. AJC cukup puas atas pelayanan klaim yang telah diberikan dan persentase terkecil sebesar 2,86\% menyatakan bahwa nasabah PT. AJC sangat tidak puas. Namun persentase 21,71\% nasabah menilai kinerja bagian klaim PT. AJC sangat memuaskan.

Dari Tabel 6 terlihat bahwa dimensi kualitas yang memiliki tingkat harapan terbesar terhadap pelayanan adalah Tangible (Bukti Fisik) sebesar 20,60\% dan dimensi yang memiliki tingkat harapan terkecil terhadap pelayanan adalah Responsiveness (Tanggapan) sebesar $19,31 \%$.

Tingkat kepentingan atau tingkat harapan pelanggan merupakan nilai kepentingan dari setiap dimensi kualitas pelayanan. Tingkat kepentingan ini akan memberikan informasi mengenai dimensi pelayanan apa yang paling penting dan sangat diharapkan oleh pelanggan. 
Tabel 6. Persentase Dimensi Kepuasan Pelanggan

\begin{tabular}{lcc}
\hline \multicolumn{1}{c}{ Dimensi Pernyataan } & $\begin{array}{c}\text { Jumlah } \\
\text { Harapan }\end{array}$ & $\begin{array}{c}\text { Persentase } \\
(\%)\end{array}$ \\
\hline Tangible (Bukti Fisik) & 383 & 20,60 \\
Reliability (Keandalan) & 362 & 19,47 \\
Responsiveness & 359 & 19,31 \\
(Tanggapan) & 380 & 20,44 \\
Assurance (Jaminan) & 375 & 20,17 \\
Emphaty (Empati) & 1859 & 100 \\
\hline TOTAL &
\end{tabular}

Dari Tabel 7 tersebut dapat dilihat bahwa dimensi kualitas yang paling penting menurut nasabah adalah dimensi bukti fisik, yaitu perlengkapan sarana dan ruang pelayanan. Penilaian tingkat kepentingan ini belumlah dapat dijadikan kesimpulan mengenai nilai kualitas pelayanan bagian klaim dari PT. AJC.

\section{Analisis Nilai Servqual Score}

Penilaian terhadap kualitas pelayanan dimaksudkan untuk menentukan prioritas perbaikan yang akan dilakukan sehingga didapatkan peningkatan kualitas pelayanan yang diinginkan. Penilaian tersebut dibuat berdasarkan dari perhitungan nilai ekspektasi dan nilai persepsi. Perhitungan servqual score adalah perhitungan yang memperlihatkan gap antara nilai ekspektasi yang diharapkan pelanggan dengan nilai persepsi yang dirasakan oleh pelanggan. Sehingga rumus untuk menghitung servqual score adalah selisih antara nilai kepuasan atau persepsi dengan niai kepentingan atau ekspektasi. Rumus yang digunakan adalah:

\section{Servqual Score $=$ Skor Persepsi - Skor Ekspektasi}

Dari Tabel 8 dapat diketahui bahwa kualitas pelayanan mendapatkan hasil nilai gap yang positif $(+)$, hal ini menunjukkan bahwa bagian klaim PT. AJC yang memberikan jasa telah mampu memberikan kualitas pelayanan yang sesuai dengan harapan nasabahnya.

Tabel 7. Persentase Tingkat Kepentingan

\begin{tabular}{llrr}
\hline & \multicolumn{1}{c}{ Dimensi Pelayanan } & $\begin{array}{c}\text { Tingkat } \\
\text { Kepentingan }\end{array}$ & $\begin{array}{c}\text { Persentase } \\
(\%)\end{array}$ \\
\hline X1.1 & Kebersihan dan kenyamanan ruang kantor & 3,54 & 6,67 \\
X1.2 & Perlengkapan sarana dan ruang pelayanan & 3,89 & 7,32 \\
X1.3 & Peralatan dan teknologi yang dimiliki & 3,51 & 6,62 \\
X2.1 & Transaksi dilakukan dengan tepat dan bebas kesalahan & 3,29 & 6,19 \\
X2.2 & Karyawan mampu memberikan informasi yang diperlukan oleh nasabah & 3,57 & 6,72 \\
X2.3 & Prosedur pelayanan klaim yang mudah dimengerti & 3,49 & 6,56 \\
X3.1 & Respon cepat yang diberikan karyawan kepada nasabah bila ada masalah & 3,29 & 6,19 \\
X3.2 & Kecepatan pembayaran klaim & 3,43 & 6,46 \\
X3.3 & Kemudahan dihubungi melalui telepon & 3,54 & 6,67 \\
X4.1 & Ketelitian karyawan saat melayani pelanggan & 3,77 & 7,10 \\
X4.2 & Profesionalisme karyawan dalam bekerja & 3,57 & 6,72 \\
X4.3 & Tingkat premi yang bersaing & 3,51 & 6,62 \\
X5.1 & Keramahan dan kesopanan karyawan dalam melayani pelanggan & 3,60 & 6,78 \\
X5.2 & Hubungan interaktif antara karyawan dengan nasabah & 3,60 & 6,78 \\
X5.3 & Etika berkomunikasi melalui telepon & 3,51 & 6,62 \\
\hline
\end{tabular}

Tabel 8. Nilai Rata-rata GAP Berdasarkan 5 Dimensi

\begin{tabular}{lccccc}
\hline \multirow{2}{*}{ Dimensi Pernyataan } & \multicolumn{2}{c}{ Jumlah Rata-rata } & \multicolumn{2}{c}{ Nilai } & Gap \\
\cline { 2 - 5 } & Kinerja & Harapan & Kinerja & Harapan & Score \\
\hline Tangible (Bukti Fisik) & 135,33 & 127,67 & 3,87 & 3,65 & 0,22 \\
Reliability (Keandalan) & 134,00 & 120,67 & 3,83 & 3,45 & 0,38 \\
Responsiveness (Tanggapan) & 136,33 & 119,67 & 3,90 & 3,42 & 0,48 \\
Assurance (Jaminan) & 12933 & 126,67 & 3,70 & 3,62 & 0,08 \\
Emphaty (Empati) & 130,67 & 125,00 & 3,73 & 3,57 & 0,16 \\
\hline
\end{tabular}


Tabel 9. Nilai Kinerja Pelanggan

\begin{tabular}{|c|c|c|c|c|c|c|c|}
\hline \multirow{3}{*}{ Pernyataan } & \multicolumn{5}{|c|}{ Tanggapan Responden } & \multirow{3}{*}{ Total } & \multirow{3}{*}{$\begin{array}{l}\text { Nilai } \\
\text { Kinerja }\end{array}$} \\
\hline & STP & TP & $\mathrm{CP}$ & $\mathrm{P}$ & SP & & \\
\hline & 1 & 2 & 3 & 4 & 5 & & \\
\hline Kebersihan dan kenyamanan ruang kantor & 0 & 0 & 12 & 15 & 8 & 136 & 3,89 \\
\hline Perlengkapan sarana dan ruang pelayanan & 0 & 0 & 12 & 13 & 10 & 138 & 3,94 \\
\hline Peralatan dan teknologi yang dimiliki & 0 & 0 & 15 & 13 & 7 & 132 & 3,77 \\
\hline Transaksi dilakukan dengan tepat dan bebas kesalahan & 0 & 0 & 19 & 10 & 6 & 127 & 3,63 \\
\hline $\begin{array}{l}\text { Karyawan mampu memberikan informasi yang } \\
\text { diperlukan oleh nasabah }\end{array}$ & 0 & 0 & 9 & 17 & 9 & 140 & 4 \\
\hline Prosedur pelayanan klaim yang mudah dimengerti & 0 & 0 & 11 & 18 & 6 & 135 & 3,86 \\
\hline $\begin{array}{l}\text { Respon cepat yang diberikan karyawan kepada } \\
\text { nasabah bila ada masalah }\end{array}$ & 0 & 0 & 16 & 14 & 5 & 129 & 3,69 \\
\hline Kecepatan pembayaran klaim & 0 & 0 & 14 & 12 & 9 & 135 & 3,86 \\
\hline Kemudahan dihubungi melalui telepon & 0 & 0 & 10 & 10 & 15 & 145 & 4,14 \\
\hline Ketelitian karyawan saat melayani pelanggan & 0 & 0 & 18 & 12 & 5 & 127 & 3,63 \\
\hline Profesionalisme karyawan dalam bekerja & 0 & 0 & 19 & 12 & 4 & 125 & 3,57 \\
\hline Tingkat premi yang bersaing & 0 & 0 & 14 & 11 & 10 & 136 & 3,89 \\
\hline $\begin{array}{l}\text { Keramahan dan kesopanan karyawan dalam melayani } \\
\text { pelanggan }\end{array}$ & 0 & 0 & 15 & 16 & 4 & 129 & 3,69 \\
\hline Hubungan interaktif antara karyawan dengan nasabah & 0 & 0 & 14 & 11 & 10 & 136 & 3,89 \\
\hline Etika berkomunikasi melalui telepon & 0 & 0 & 19 & 10 & 6 & 127 & 3,63 \\
\hline JUMLAH & 0 & 0 & 217 & 194 & 114 & 1997 & 57,06 \\
\hline RATA-RATA & 0 & 0 & 14,5 & 12,9 & 7,6 & 133,1 & 3,8 \\
\hline
\end{tabular}

Tabel 10. Nilai Harapan Pelanggan

\begin{tabular}{|c|c|c|c|c|c|c|c|}
\hline \multirow{3}{*}{ Pernyataan } & \multicolumn{5}{|c|}{ Tanggapan Responden } & \multirow{3}{*}{ Total } & \multirow{3}{*}{$\begin{array}{r}\text { Nilai } \\
\text { Harapan }\end{array}$} \\
\hline & STP & TP & $\mathrm{CP}$ & $\mathrm{P}$ & SP & & \\
\hline & 1 & 2 & 3 & 4 & 5 & & \\
\hline Kebersihan dan kenyamanan ruang kantor & 1 & 2 & 16 & 9 & 7 & 124 & 3,54 \\
\hline Perlengkapan sarana dan ruang pelayanan & 0 & 3 & 8 & 14 & 10 & 136 & 3,89 \\
\hline Peralatan dan teknologi yang dimiliki & 1 & 2 & 18 & 6 & 8 & 123 & 3,51 \\
\hline Transaksi dilakukan dengan tepat dan bebas kesalahan & 3 & 5 & 14 & 5 & 8 & 115 & 3,29 \\
\hline $\begin{array}{l}\text { Karyawan mampu memberikan informasi yang } \\
\text { diperlukan oleh nasabah }\end{array}$ & 1 & 1 & 16 & 11 & 6 & 125 & 3,57 \\
\hline Prosedur pelayanan klaim yang mudah dimengerti & 0 & 3 & 16 & 12 & 4 & 122 & 3,49 \\
\hline $\begin{array}{l}\text { Respon cepat yang diberikan karyawan kepada nasabah } \\
\text { bila ada masalah }\end{array}$ & 0 & 4 & 21 & 6 & 4 & 115 & 3,29 \\
\hline Kecepatan pembayaran klaim & 2 & 4 & 14 & 7 & 8 & 120 & 3,43 \\
\hline Kemudahan dihubungi melalui telepon & 1 & 2 & 16 & 9 & 7 & 124 & 3,54 \\
\hline Ketelitian karyawan saat melayani pelanggan & 2 & 1 & 8 & 16 & 8 & 132 & 3,77 \\
\hline Profesionalisme karyawan dalam bekerja & 2 & 4 & 12 & 6 & 11 & 125 & 3,57 \\
\hline Tingkat premi yang bersaing & 1 & 5 & 12 & 9 & 8 & 123 & 3,51 \\
\hline $\begin{array}{l}\text { Keramahan dan kesopanan karyawan dalam melayani } \\
\text { pelanggan }\end{array}$ & 0 & 2 & 18 & 7 & 8 & 126 & 3,6 \\
\hline Hubungan interaktif antara karyawan dengan nasabah & 1 & 3 & 13 & 10 & 8 & 126 & 3,6 \\
\hline Etika berkomunikasi melalui telepon & 0 & 4 & 18 & 4 & 9 & 123 & 3,51 \\
\hline JUMLAH & 15 & 45 & 220 & 131 & 114 & 1859 & 53,11 \\
\hline RATA-RATA & 1 & 3 & 14,7 & 8,73 & 7,6 & 123,9 & 3,54 \\
\hline
\end{tabular}

\section{Grafik Kartesius}

Untuk mengetahui tingkat kepuasan pengguna jasa pelayanan klaim PT. AJC yaitu dengan membandingkan antara rata-rata pelaksanaan $(\mathrm{X})$ dengan rata-rata kepentingan pelanggan (Y).

Setelah diketahui skor rata-rata tingkat pelaksanaan dan skor rata-rata tingkat kepentingan, selanjutnya nilai dimasukan ke dalam grafik kartesius, dimana diagram tersebut dibagi menjadi empat kuadran (Gambar 2). Diagram ini terdiri dari empat kuadran: kuadran pertama terletak di sebelah kiri atas, kuadran kedua di sebelah kanan atas, kuadran ketiga di sebelah kiri bawah, dan kuadran keempat di kanan bawah. Di bawah ini dapat dilihat grafik 
Tabel 11. Nilai X Rata-rata dan Y Rata-rata untuk Grafik Kartesius

\begin{tabular}{cccc}
\hline NO & VARIABEL & \multicolumn{1}{c}{ KETERANGAN } & SKOR \\
\hline 1 & $\mathrm{X}$ & Tingkat kinerja (Persepsi pelanggan) & 3,80 \\
2 & $\mathrm{Y}$ & Tingkat harapan pelanggan & 3,54 \\
\hline
\end{tabular}

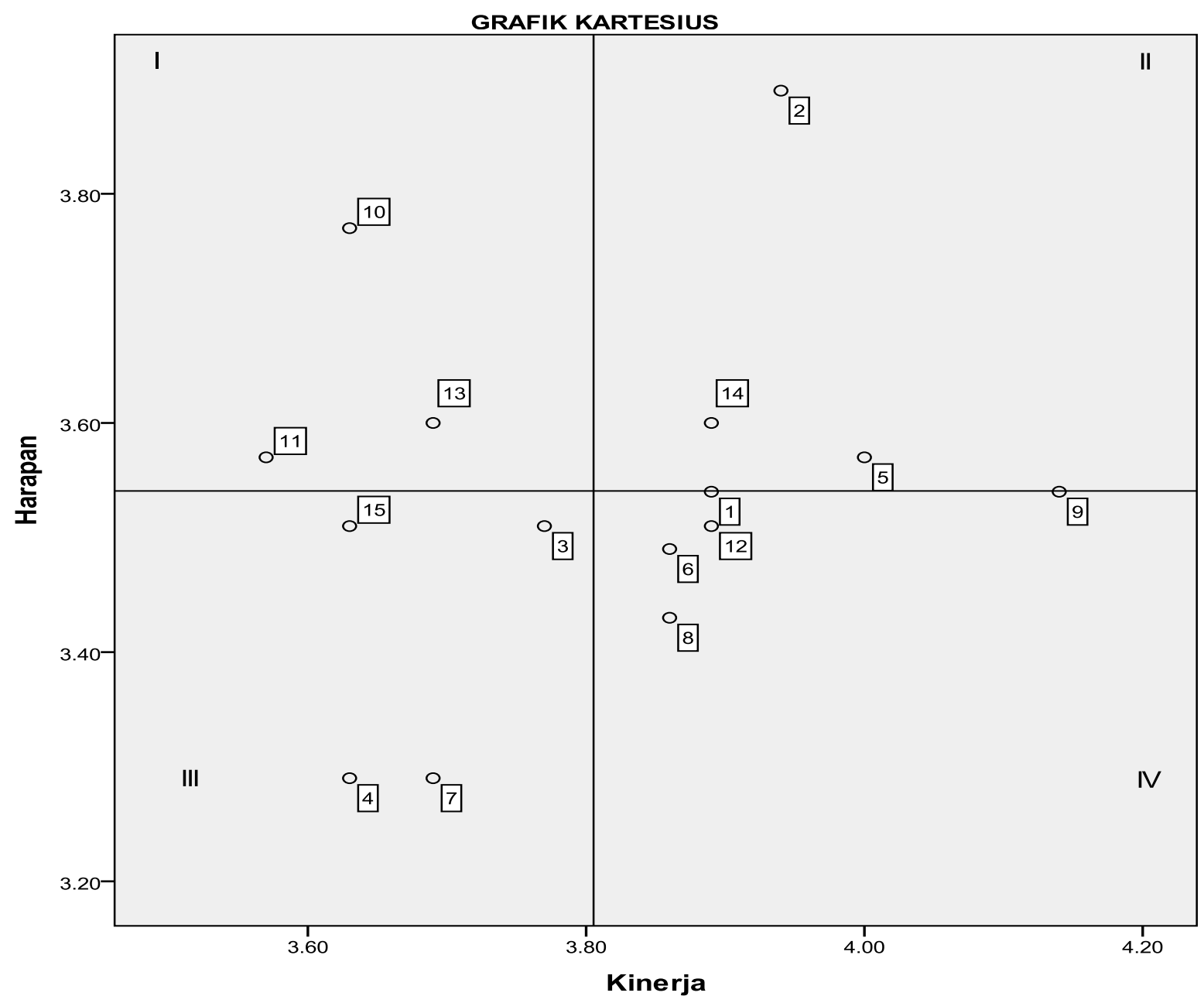

Gambar 2. Grafik Kartesius Atribut Pelayanan Bagian Klaim PT. AJC

kartesius terhadap kinerja dan harapan pelanggan.

Dari Gambar 2 dapat dilihat, bahwa variabel-variabel mana saja yang masuk ke kuadran I, II, II dan IV.

a. Kuadran I (Prioritas utama):

Ketelitian karyawan saat melayani pelanggan dan profesionalisme karyawan dalam bekerja

b. Kuadran II (Pertahankan prestasi):

Kebersihan dan kenyamanan ruang kantor, perlengkapan sarana dan ruang pelayanan, karyawan mampu memberikan informasi yang diperlukan oleh nasabah, kemudahan dihubungi melalui telepon dan hubungan interaktif antara karyawan dengan nasabah. c. Kuadaran III (Prioritas rendah):

Peralatan dan teknologi yang dimiliki, transaksi dilakukan dengan tepat dan bebas kesalahan, respon cepat yang diberikan karyawan kepada nasabah bila ada masalah dan etika berkomunikasi melalui telepon

d. Kuadran IV (Berlebihan):

Prosedur pelayanan klaim yang mudah dimengerti, kecepatan pembayaran klaim dan tingkat premi yang bersaing.

\section{KESIMPULAN}

Berdasarkan hasil analisis maka dapat menarik diperoleh kesimpulan: berdasarkan analisis service score, dapat diketahui bahwa kualitas pelayanan mendapatkan hasil nilai gap 
yang positif $(+)$, hal ini menunjukkan bahwa bagian klaim PT. AJC yang memberikan jasa telah mampu memberikan kualitas pelayanan yang sesuai dengan harapan nasabahnya. Dimensi kualitas yang memiliki tingkat harapan terbesar terhadap pelayanan adalah Tangible (Bukti Fisik) sebesar 20.60\% dan yang penting bagi nasabah adalah atribut perlengkapan sarana dan ruang pelayanan.

\section{DAFTAR PUSTAKA}

[1]. Tjiptono Fandy, 2004, Strategi Pemasaran, Edisi 2, Penerbit Andi, Yogyakarta.

[2]. Gerson, Richard. F. 2004. Mengukur Kepuasan Pelanggan, PPM, Jakarta.
[3]. Kotler, Philip. 2002. Manajemen Pemasaran. Jilid 1\&2. Edisi Milenium. Jakarta: Prehalindo.

[4]. Rangkuti, Freddy. 2002. Measuring Customer satisfaction. PT. Gramedia Pustaka Utama, Jakarta

[5]. Kotler, Philip dan A.B. Susanto. 2000. Manajemen Pemasaran di Indonesia. Salemba Empat, Jakarta.

[6]. Berry dan Zeithaml, dikutip oleh Handi Irawan, 2003, Manajemen Pemasaran, Bandung.

[7]. Sulastomo, Dr. MPH. 1997, Asuransi Kesehatan dan Managed Care, Jakarta: PT. (Persero) Asuransi Kesehatan Indonesia. 